ISSN 2414-1143

Научный альманах стран Причерноморья. 2021. Том 26. № 2

DOI 10.23947/2414-1143-2021-26-2-27-34

UDC 316.7

\title{
IDENTITY OF STUDENT YOUTH AND NEW SOCIAL REALITY
}

\author{
(C) Sarat G. Hiyasova, Maida G. Mustafaeva, Elmira Sh. Musaeva
}

\author{
Dagestan State Pedagogical University, Makhachkala, Republic of Dagestan, \\ Russian Federation \\ science-almanac@mail.ru
}

The degree of influence of the Internet environment on young people in modern culture is analyzed. It is noted that at the present stage, society and culture have ceased to be considered the main institutions of socialization, which play a major role in personal identification issues. This niche has been occupied by the global network and information and communicative space. There is a need for young people to develop critical thinking skills and media literacy, since their absence can have a number of negative consequences, from conflicts on religious grounds to violation of ethno-national and civic identity. The audience questionnaire was conducted, it was revealed that the goals of visiting social networks by young people are different in the different age range. And if in one case the Internet environment is used for educational and cognitive purposes, as a convenient platform for obtaining information, then in another case it is used for entertainment and leisure. At the present stage, due to the excessive immersion of young people in the Internet environment, processes of uncontrolled socialization are observed, as well as the formation of false identities, when it is appropriate to talk about the diversity of manifestations of their "own self" among young people. The article recommends to subject the study of the real motives of "immersion" of young people in the virtual reality, which will allow specialists to help young people in matters of self-identification, individual choice of the behavior model that would correspond to their true essence.

Key words: identity, youth, Internet, Network, communications, space, education, personal development.

\section{[С.Г. Хиясова, М.Г. Мустафаева, Э.Ш. Мусаева Идентичность студенческой молодежи и новая социальная реальность]}

Анализируется степень влияния интернет-пространства на молодежь в современной культуре. Отмечается, что на современном этапе общество и культура перестали считаться основными институтами социализации, которые играют главную роль в вопросах идентификации личности. Эту нишу заняли глобальная сеть и информационно-коммуникативное пространство. Отмечаются необходимость развития у молодежи навыков критического мышления и медийной грамотности, т.к. их отсутствие может иметь ряд негативных последствий, начиная от конфлликтов на религиозной почве, до нарушения этнонациональной и гражданской идентификации. Проведено аудиторное анкетирование, выявлено, что цели посещения социальных сетей молодежью различны в разном возрастном диапазоне. И если в одном случае интернет-пространство используется в образовательнопознавательных целях как удобная площадка для получения информации, то в другом - в целях развлечения и досуга. На современном этапе вследствие чрезмерного погружения молодежи в интернет-пространство наблюдаются процессы неконтролируемой социализации, а также формирования ложной идентичности, когда уместно говорить о многообразии проявлений у молодежи «собственного Я». Рекомендуется сделать объектом специального исследования изучение настоящих мотивов «погружения» молодежи в виртуальную реальность, что позволит специалистам оказать помощь молодежи в вопросах самоидентификации, индивидуального выбора той модели поведения, которая соответствовала бы их истинной сущности.

Ключевые слова: идентичность, молодежь, интернет, Сеть, коммуникации, пространство, образование, воспитание.

Sarat G. Hiyasova - Ph.D. in Pedagogy, Associate Professor, Dagestan State Pedagogical University, Makhachkala, Republic of Dagestan, Russian Federation.

Maida G. Mustafaeva - Ph.D. (Advanced Doctorate) in Philosophy, Professor, Dagestan State Pedagogical University, Makhachkala, Republic of Dagestan, Russian Federation. 
Elmira Sh. Musaeva - Ph.D. in Philosophy, Associate Professor, Dagestan State Pedagogical University, Makhachkala, Republic of Dagestan, Russian Federation.

Хиясова Сарат Гасановна - кандидат педагогических наук, доцент, Дагестанский государственный педагогический университет, г. Махачкала, Республика Дагестан, Российская Федерация.

Мустафраева Маида Ганифраевна - доктор фрилософрских наук, профрессор, Дагестанский государственный педагогический университет, г. Махачкала, Республика Дагестан, Российская Федерация.

Мусаева Эльмира Шекералиевна - кандидат фрилософрских наук, доцент, Дагестанский государственный педагогический университет, г. Махачкала, Республика Дагестан, Российская Федерация.

Understanding the problem of the interaction between the Internet environment and the social identity of youth is considered by many authors, such as E.V. Alistratova, Yu.D. Babaeva, E.P. Belinskaya, N.V. Grin, A.E. Zhichina, D.V. Ivanov and others. [3; 11]

It is common knowledge that a person's sense of belonging to a particular sociocultural space, the identity of a person, is formed as a result of socialization and acculturation, and the end result of these processes is the formation of a person adequate to society. It is difficult to overestimate the importance of identity for a person, a society, because, identifying ourselves with a certain socio-cultural space, we feel like a part of this space, the society and at the same time do not lose our uniqueness, personal peculiarity.

The objective reality is that at present, young people have a large range of options and a certain freedom to build a model for positioning their own self. And today, at the modern stage of the development of society, we are witnessing processes when the society itself and culture no longer play such a significant role in matters of personality identification. This role niche has been occupied by the global network and information and communicative space, which gave young people complete freedom of choice in this matter. But this seemingly attractive freedom in self-determination of the choice of personality at the same time imposes a number of obligations on a person: what type of identification model to choose, when should the person stop so as not to completely lose Himself. The problem is the difficulty of searching due to the wide choice of models, various personal identification options. In addition, in the modern sociocultural space, value orientations are blurred, there is no integrity and certainty in this issue. In this regard, today the phenomenon of uncontrolled socialization is recalled more often. Uncontrolled socialization is an impact on the consciousness of young people of information flows not in terms of a planned and verified course, but naturally, if not randomly. Examples of such socialization can be cases of youth facing on social media with any doubtful information that causes a sense of social inequality or national discord, which can inspire destructive actions, or attempts to involve young people in suicidal, network communities. All this, of course, cannot but affect the consciousness of young people. At the same time, it is important to note that the presence of so-called critical thinking skills, as well as media literacy skills, formed including in the process of education and personal development, will help to avoid the harmful influence of the Network. We also consider the modern trend to be dangerous, when the lack of critical thinking in general, and individual knowledge, in particular, is used by third parties to exacerbate conflicts on religious grounds. Religious and political extremism can become a consequence of this trend. Extremism and its manifestations in the Internet environment openly expose its extreme, intolerable ideas as a part of doctrinal statements of traditional religions. Many regions of the North Caucasus have already faced this problem. In fact, this is a relevant in modern culture phenomenon, when the low level of religious knowledge, religious culture is proportional to the great desire to quickly obtain information in this area and preferably not from books of authoritative scientists, researchers, but from the Internet. 
Considering that nowadays young people are in the digital environment from the school age, and the Internet is the source of a variety of, sometimes contradictory, information, the effect of such education is similar to a time bomb.

The characteristic feature of the new social space was also the loss of understanding by students of their place in society and it is appropriate to talk about violation of ethnonational and civil identification.

Specialists at all levels, including teachers, psychologists, and parents themselves express concern that in modern life, the younger generation prefers virtual communication to simple human communication. At the same time, young people whose active socialization takes place in the digital environment as a social environment due to the widespread of digital technologies are called by various authors as "digital generation," "network generation," "digital aborigines." [7, pp. 6-7] This trend is greatly facilitated by the fact that the younger generation finds here everything that cannot always find in real life, for example, more emotional communication based on anonymity of communication on the network. Thus, the popularity of virtual communication is largely due to the fact that here modern youth can transform their identity, creating new attractive images that are most likely not always possible to realize in everyday life. At the same time, the new generation is quite receptive to innovation, quickly learns uncharted spaces, includes them in its life.

Factors that represent the communicative Internet environment as attractive to the younger generation include:

- Possibilities of extensive communication;

- Wide access to information and databases;

- Great opportunities for self-education and self-development, as well as for selfexpression, dissemination of creativity and potential;

- Lack of territorial boundaries;

- Interpersonal communication difficulties are overcome by replacing this communication with a virtual one.

In the study, R.M. Aisina, A.A. Nesterova also highlight positive aspects of young people's mastery of cyberspace, while noting the most dangerous risks and barriers of cyber socialization for modern young people. They also distinguish the types and levels of cybersocialization of youth, such as positive and negative. The positive vector of cybersocialization is determined by them as the ability of a young person to transfer the useful experience gained in cyberspace to everyday life. [2]

There was also no consensus among psychologists about the psychological impact of Internet technologies on the forming person. So, for example, N.S. Kozlova writes: "We proceed from the fact that virtual space itself is not able to initially set the pole of its influence. In fact, the Internet is indifferent to personality. The consequences depend on the sociopsychological characteristics of the persons involved in the network." [4, p. 275]

In contrast, K.S. Yang found that depression correlates with Internet addiction. Depressed patients who are more afraid of rejection than others and more in need of social support use the Internet to overcome the difficulties of interpersonal interaction in reality. [13, p. 24-29] It is also believed that the deterioration of interpersonal relations in reality leads to Internet dependence. [9; 10]

So, at the modern socio-historical stage, the formation of youth identity is greatly influenced by the information and communicative Internet environment or global network, which has long ceased to be just a system for storing and transmitting large amounts of information. Therefore, today we often face a phenomenon when modern youth manifest a variety of models of manifestation of their own self. This is also due to the fact that, by presenting himself in the Internet environment, a young man, a student is independent of his own physical and biographical characteristics, which gives him the opportunity for new self-determination and often leads to false identity. Observations show that in the Internet 
environment, very often young people hide behind some image that does not correspond, but often opposes their true essence. Unfortunately, the student here is more eager to seem than to be. At the same time, the most dangerous thing in this situation is that the model of behavior chosen for imitation, the way of thinking, eventually become familiar, and then it is very difficult for a person to get rid of the "mask," and this subsequently threatens him to become an object deprived of his own face. There is also a risk that the identity formed in fictional images is deprived of authenticity, and it is superficial. We consider that the key role in this issue is also played by the fact that for the identity of modern youth, the need for recognition by others is particularly relevant, and in this desire the student, the young man often sacrifices his own needs and his essence in favor of one or another fashionable model of behavior.

Thus, a certain existence of youth in virtual reality turns out to be more convenient and attractive than objective reality itself. The person lives more in ideas about the world and about himself than in the world itself and in his own essence. Here, virtual hyperreality acquires the status of a new living space of an individual and creates new ways of identification.

Often, colourful Internet pages of students provide some useful information about their owners for both teachers and psychologists, because in some cases, how they position themselves in the Internet environment, what they post in their profiles is not who they really are, but what they might want to be, what they see themselves in their imagination. Hence, social networks are often a kind of platform where young people try to imagine a kind of ideal image of themselves.

Most likely, the one whose presentation of his own imaginary "I" will be more interesting and colorful is more successful here. Thus, according to V.V. Kochetkov, in fact, we are dealing with the innate quality of a person, that is the tendency to represent ourselves better than we really are. Considering the problems of identity from the point of view of various scientific schools, the author points to the theory of compensation of A. Adler, who noted that the person is driven by the desire for superiority. [1] Developing this idea, the author notes that "every person is born with a desire for superiority, but it is not always possible to realize it due to physiological or psychological characteristics. Therefore, all mankind suffers from a feeling of inferiority due to shortcomings or failures." Therefore, "to overcome the feeling of inferiority, the person resorts to compensation. In the process of compensation, the person develops an individual life style that transforms into identity." [5]

Thus, the current reality is that most Internet users from the youth environment have a high or very high level of Internet dependence, which is expressed in their daily visiting to the global Internet, spending on the Networks usually more time than originally planned. This process is usually accompanied by the fact that young people often postpone all their affairs because of the Internet. At the same time, neither young people nor their parents are fully aware of the fact that the network space can be a big evil, since the control over the content of Internet resources is minimal.

As part of this problem, we conducted an audience questionnaire among the students of the Art and Graphic Faculty of the DSPU (4-5 courses) and the students of the 9th forms of gymnasium school No. 37 in Makhachkala. The main goal of the research was to identify the motives for visiting social networks. [8, pp. 3180-3193; 11]

As a result of the analysis of respondents' answers, it was found that the main purpose of visiting the Internet among high school students at school is, first of all, to watch videos, download music, video, etc. (70\%), in the second place there is communication with friends on topics of interest (55\%), and in the third place there is the search for friends, like-minded people for interests and communication with them (42\%). A relatively small proportion of respondents (30\%) indicated that the purpose of visiting social networks is to obtain information for study. However, when analyzing the questionnaires of university students on 
similar issues, the other percentage was revealed. So, for example, in their questionnaires, students noted that first of all, the purpose of visiting the Internet is to obtain information for study (75\%). A significant part of respondents, unlike schoolchildren, indicated that social networks are a means of expression for them, help to declare themselves and publish their work for the general public (40\%), 10\% of respondents indicated that social networks help in finding work and services, and communication with friends takes $10 \%$.

As for the overall role of social networks in shaping their identity and psychological state, more than half of respondents (65\%) noted a positive or rather positive impact. An extremely negative impact was noted by $22 \%$. At the same time, about $16 \%$ of respondents believe that social networks do not have any influence on them.

Analyzing the data of the audience questionnaire, we revealed that the purposes of visiting social networks by high school students and university students can vary. So, if in the first case the possibilities of social networks are used mainly for entertainment purposes, then in the second case the Internet is used as a means of obtaining useful information and some kind of means of self-expression. Therefore, the conclusion is that in this particular case, the Internet environment is used for different purposes, which is determined by age, various interests. What ultimately has a greater impact on these preferences: age, the influence of the educational environment, family or the immediate circle has yet to be clarified by specialists. In their article O.A. Maksimova, E.O. Shandrik point to the relevance and need for further study of this problem. They emphasize that communicative networks and digital technologies act as an important factor in youth self-identification. [7]

The conditions when a person is able to effectively integrate into a virtual environment include: social experience, the presence of special knowledge, the stability of mental processes, the stability of views, the ability to critically perceive their actions. At the same time, assessing the degree of influence of Internet communications on young people, in our opinion, it is important to be able to determine the individual degree of influence of the Network on the consciousness and mind of each individual.

It should be noted that when the Internet environment is used by young people for education, as a convenient platform for obtaining information, as a progressive tool that gives great opportunities for self-education and self-development, there is no reason for concern, since it hardly makes sense to talk about the appearance of a special reality in the life of the user. In the case when staying on the Web from the purpose turns into the motive, then the information capabilities of the Internet allow a person to immerse himself in the virtual reality, a holistic, active and autonomous habitat. In our opinion, this should serve as a cause for concern, since "non-living" communication separates the young generation from the real world, real communication, which is very valuable for the development of a person as a full individual, disrupts normal socialization and identification. Hence, we consider that it is necessary to subject the study of the real motives of "immersing" of young people in the virtual reality. Thus, there is a possibility of studying the objective "reality" in which young people reside in a particular time period. All this will allow specialists to help young people in matters of self-identification, individual choice of the behavior model that would correspond to their true essence, to carry out preventive and psychocorrective work in this direction in time. The study can be carried out on the example of such popular networks as Instagram, Vkontakte, Odnoklassniki, etc.

Thus, as a result of the analysis of a number of works of specialists in a problem of identity of youth and influence on this process of Internet environment and also as a result of the research conducted by us we came to the following conclusions:

1. At the present stage, there is a long and prolonged influence of the global network and the information communication environment on the process of youth self-identification.

2. In conditions when value orientations are blurred, a prolonged stay of young people on the Internet can contribute to uncontrolled socialization. At the same time, the tendency 
in modern society of irresponsibility for any actions and statements on the Web contributes to the manifestation of destructive actions in interaction (such as the formation of a sense of social inequality or national discord, religious and political extremism, etc.).

3 . The role of the Internet and media is ambiguous: both positive and negative aspects stand out. There is also no consensus among psychologists on the psychological impact of Internet technologies on the forming person.

4. The excessive presence of young people on the Web is fraught with the formation of a false identity, when it is appropriate to talk about the diversity of manifestations of "own self," the formation of an image among students that may not correspond to their real essence.

5. Our research has shown that the main purposes of visiting the Internet (entertaining or cognitive) may be directly dependent on the age segment.

6 . As a result of the analysis of a number of works, it was revealed that the conditions for the successful integration of young people into a virtual environment include: social experience, the presence of special knowledge, the stability of psychological processes, the stability of views, the possession of critical thinking skills, the ability to critically perceive their own actions.

7. In conditions when staying on the Web from the purpose turns into the motive, the information capabilities of the Internet allow a person to immerse himself in the virtual reality, a holistic, active and autonomous habitat.

8. It is necessary to subject the study of the real motives of "immersing" of young people in the virtual reality that will allow specialists to help young people in matters of selfidentification, to carry out preventive and psychocorrective work in this direction in time.

\section{Лumepamypa}

1. Адлер А. Наука жить. Комплекс неполноценности и комплекс превосходства. Киев, 1997.

2. Айсина Р.М., Нестерова А.А. Киберсоциализация молодежи в информационнокоммуникационном пространстве современного мира: эффректы и риски. Социальная психология и общество. 2019 г. Том 10. № 4.

3. Алиев М.А., Мусаева Э.Ш., Умалатова З.М. Методология и методы научнопедагогических исследований. Махачкала, 2018.

4. Козлова Н.С. Влияние интернет-среды на личность и ее жизнедеятельность // Знание. Понимание. Умение. 2015. № 3. С. 274-283.

5. Кочетков В.В. Национальная и этническая идентичность в современном мире. Вестник Московского университета. Сер. Социология и политология. 2012. № 2.

6. Куприян Н. Интернет как социальный френомен. Причины возникновения новой жизни общества. М., 2002. Т. 1.

7. Максимова О.А. «Цифровое» поколение: стиль жизни и конструирование идентичности в виртуальном пространстве // Вестник Челябинского государственного университета. - 2013. - № 22 (313).

8. Мусаева Н.Ф., Хиясова С.Г. Становление художественно-педагогического образования в Дагестане 1970-1990-е годы // В мире научных открытий. 2014. № 11-8 (59).

9. Мустафраева М.Г. Межнациональное общение в контексте социальнофрилософского анализа. Махачкала, 2019.

10. Сорокин О.В. Социальная реальность как фактор регуляции девиантного поведения российской молодежи // Мир психологии. 2018. № 3(95). 
11. Хиясова С.Г., Мусаева Э.Ш. Культурология. Учебно-методическое пособие. Махачкала, 2018.

12. Шиняева О.В., Холкина К.Д. Социальная идентификация молодежи в условиях цифрофизации российского общества. Проблемы социальной идентификации Российской молодежи: Содержательный и коммуникативный аспекты: Всероссийская научно-практическая конференция. Ульяновск, 29-30 октября. 2019 г.

13. Янг К.С. Диагноз - интернет-зависимость // Мир Интернет. 2000. № 2.

\section{References}

1. Adler A. Nauka zhit. Kompleks nepolnotsennosti i kompleks prevoskhodstva [The science of living. Inferiority complex and superiority complex]. Kiev.1997 (in Russian).

2. Aisina R.M., Nesterova A.A. Kibersotsializatsiia molodezhi v informatsionnokommunikatsionnom prostranstve sovremennogo mira: effekty i riski. Sotsialnaia psikhologiia i obshchestvo [Cybersocialization of youth in the information and communication environment of the modern world: effects and risks. Social psychology and society]. 2019. V. 10. No. 4 (in Russian).

3. Aliev M.A., Musaeva E.Sh., Umalatova Z.M. Metodologiia i metody nauchnopedagogicheskikh issledovanii [Methodology and methods of scientific and pedagogical research]. Makhachkala. 2018 (in Russian).

4. Kozlova N.S. Vliianie internet-sredy na lichnost i ee zhiznedeiatelnost. Znanie. Ponimanie. Umenie [Influence of the Internet environment on personality and the vital activities. Knowledge. Understanding. Skill]. 2015. No. 3. pp. 274-283 (in Russian).

5. Kochetkov V.V. Natsionalnaia i etnicheskaia identichnost $v$ sovremennom mire. [National and ethnic identity in the modern world]. Vestnik Moskovskogo universiteta. Ser. Sotsiologiia i politologiia. 2012. No. 2 (in Russian).

6. Kupriyan N. Internet kak sotsialnyi fenomen. Prichiny vozniknoveniia novoi zhizni obshchestva [Internet as a social phenomenon. Reasons for the emergence of a new life of society]. Moscow. 2002. V. 1 (in Russian).

7. Maksimova O.A. "Tsifrovoe" pokolenie: stil zhizni i konstruirovanie identichnosti v virtualnom prostranstve. Vestnik Cheliabinskogo gosudarstvennogo universiteta ["Digital" generation: lifestyle and identity design in virtual environment. Bulletin of Chelyabinsk State University]. 2013. No. 22 (313) (in Russian).

8. Musaeva N.F., Khiiasova S.G. Stanovlenie khudozhestvenno-pedagogicheskogo obrazovaniia v Dagestane 1970-1990-e gody. V mire nauchnykh otkrytii [Formation of art and pedagogical education in Dagestan 1970-1990s. In the world of scientific discoveries]. 2014. No. 11-8 (59) (in Russian).

9. Mustafaeva M.G. Mezhnatsionalnoe obshchenie v kontekste sotsialno-filosofskogo analiza [Interethnic communication in the context of socio-philosophical analysis]. Makhachkala. 2019 (in Russian).

10. Sorokin O.V. Sotsialnaia realnost kak faktor reguliatsii deviantnogo povedeniia rossiiskoi molodezhi. Mir psikhologii [Social reality as a factor in the regulation of deviant behavior of Russian youth. The world of psychology]. 2018. No. 3(95) (in Russian).

11. Khiiasova S.G., Musaeva E.Sh. KULTUROLOGIA. Uchebno-metodicheskoe posobie [CULTURAL STUDIES. Study guide]. Makhachkala. 2018 (in Russian).

12. Shiniaeva O.V., Kholkina K.D. Sotsialnaia identifikatsiia molodezhi v usloviiakh tsifrofizatsii rossiiskogo obshchestva. Problemy sotsialnoi identifikatsii Rossiiskoi molodezhi: Soderzhatelnyi i kommunikativnyi aspekty: Vserossiiskaia nauchnoprakticheskaia konferentsiia [Social identification of youth in the conditions of digital 
ISSN 2414-1143

Научный альманах стран Причерноморья. 2021. Том 26. № 2

profiling of Russian society. Problems of social identification of Russian youth: Informative and communicative aspects: All-Russian Scientific and Practical Conference]. Ulyanovsk, October 29-30. 2019 (in Russian).

13. Yang K.S. Diagnoz - internet-zavisimost. Mir Internet [Diagnosis - Internet addiction. World Internet]. 2000. No. 2. (in Russian). 